\section{Medisinsk biokjemi i lommeformat}

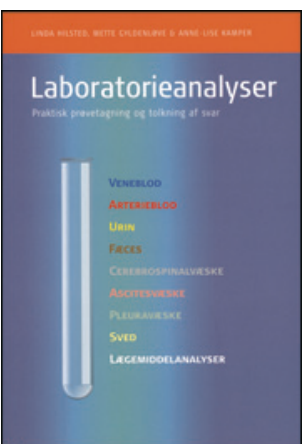

Linda Maria Hilsted, Mette Gyldenløve,

Anne-Lise Kamper

Laboratorieanalyser

Praktisk prøvetagning og tolkning af svar 222 s, tab, ill. København: Munksgaard, 2015 Pris DKK 255

ISBN 978-87-628-1580-3

«Kunnskap er å vite hvor man skal finne det man ikke vet» (Georg Simmel). I det daglige er det oftest informasjon av det enkle slaget som søkes: Hva er en komponents referanseområde og beslutningsgrenser, hva er tolkningsalternativer ved lave og høye verdier, hva er differensialdiagnoser ved ulike analysekombinasjoner og hva er en analyses kvalitet? I Laboratorieanalyser har forfatterne forholdt seg til dette på en utmerket måte ved å formidle informasjon i et format som raskt gjør det mulig å tilegne seg den mest nødvendige kunnskapen.

Hoveddelen består av beskrivelser av ulike analyseparametere organisert i grupper basert på prøvemateriale: veneblod, arterielt blod, urin, feces, spinalvæske, ascites, pleuravæske og svette, samt en beskrivelse av legemiddelanalyser. Hvert av kapitlene er merket med farge som gjør oppslag enkelt, og innen hvert kapittel er analysene angitt i alfabetisk rekkefølge. Analysebeskrivelsene er alle strukturert i en innledende generell beskrivelse av analysekomponenten (med fokus på biokjemi, fysiologi/patofysiologi og nytten som biokjemisk sykdomsmarkør), referanseområde, tolkning (verdier utenfor referanseintervallet) $\mathrm{og}$ indikasjon. Strukturen på analysebeskrivelsene fungerer godt, og all informasjon har høy grad av faglig kvalitet. Noen avsnitt omhandler også rekvirering og prøvetaking, generell bruk av medisinsk-biokjemiske analyser og tolkning av resultater, nomenklatur osv.

En håndbok vil nødvendigvis omfatte bare et begrenset utvalg av det totale antall analyser som er tilgjengelig innen laboratoriemedisin. Det er i forordet angitt at boken omfatter de vanlige analysene brukt på sykehusavdelinger og i allmennpraksis og er særlig ment for yngre leger. Analyserepertoaret dekker helt klart behovet for målgruppen. Analyser som med fordel kunne vært omtalt i tillegg er for eksempel P-transferrinreseptor (TfR), som brukes i økende grad i forbindelse med utredning av jernmangel og ikke minst ved anemi ved kronisk sykdom. Gitt den økende innvandringen fra fjerntliggende strøk kunne hemoglobintyping og utredning av hemoglobinopatier med fordel vært kort beskrevet.

Av de vel 150 analysene som omtales er det fem som naturlig hører inn under fagområdet immunhematologi (forlikelighetstester) og ytterligere fem som hører til klinisk immunologi (autoantistoffer). I tillegg er det et lite kapittel om legemiddelanalyser. Hvorvidt dette er tilstrekkelig til at boken skulle få den bredt favnende tittelen Laboratorieanalyser, er ikke åpenbart for undertegnede. Man kan imidlertid ikke se bort fra at begrepet laboratorieanalyse har en annen betydning i Danmark enn i Norge.

I dag er håndbøker også tilgjengelig som nettversjoner og app-er, men i mange år vil det være rom for og behov for håndbøker i papirutgave. Hvis jeg skulle velge en håndbok i papirversjon, ville jeg valgt denne «lille danske» som passer i frakkelommen og som vil gi meg raskt svar på det meste av det jeg ikke vet om enkle laboratorieanalyser.

\section{Innføring i barneanestesi}

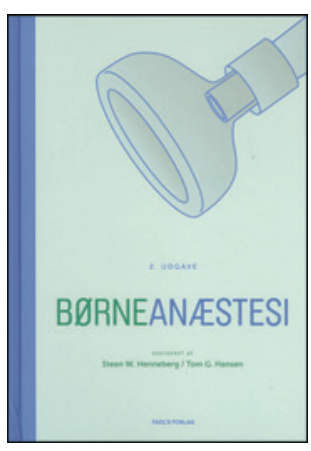

Steen W. Henneberg, Tom G. Hansen, red. Børneanæstesi

2. utg. 282 s, tab, ill. København: FADL's forlag, 2015. Pris DKK 550 ISBN 978-87-7749-729-2

I innledningen redegjør ikke redaktørene for tiltenkt målgruppe, men den synes å egne seg best som lærebok for både spesialsykepleiere og yngre anestesileger som ønsker å fordype seg innenfor barneanestesi. Den egner seg ikke som oppslagsverk, dertil er den for lite detaljert og noe upraktisk inndelt.

Kapittelforfatterne er anestesileger og spesialsykepleiere ansatt ved ulike sykehus i Danmark. Boken er delt opp i 29 hovedkapitler. De første fem omhandler basale emner innen neonatal og pediatrisk fysiologi, deretter følger kapitler om generelle aspekter ved anestes til barn og ved spesielle typer inngrep, som øre-nese-hals, thoraxkirurgi, ortopedisk kirurgi m.m. Avslutningsvis omtales spesielle forhold omkring transport av dårlige barn mellom sykehus og generell postoperativ overvåkning av barn. Det er ganske mange illustrasjoner og tabeller.

Boken hadde profittert på en noe strammere regi og kritisk gjennomgang fra redaktørene. Blant annet benyttes generika og produktnavn om hverandre. I kapitlet om anestesi ved øyekirurgi er anbefalte doseringer av visse antiemetika oppgitt i mg/kg, men skal være $\mu \mathrm{g} / \mathrm{kg}$. Det er også en god del gjentagelser i innledningene. Det savnes gjennomgående også et klarere skille mellom de ulike anestesirelaterte utfordringene hos nyfødte, spedbarn og barn, til tross for at kapitlet om anestesi til nyfødte på en utmerket måte viser utfordringene ved denne gruppen.

Selv om det er mange gode tabeller og illustrasjoner, savner jeg allikevel noen, f.eks. en illustrasjon av de ulike pediatriske anestesisystemene i kapitlet om utstyr til barneanestesi og rådgivende doseringstabeller i farmakologikapitlet. Flere av kapitlene bærer dessuten preg av oppramsing, og jeg savner retningslinjer og råd.

Kapitlene om preoperativ vurdering og forberedelse av barn og foreldre samt kapitlet om postoperativ smertebehandling av barn er veldig bra, med mange gode refleksjoner og råd. Kapittel 24 om regional anestesi samt kapittel 22 om anestesi til barn med medfødte hjertesykdommer som skal ha ikke-hjertekirurgiske inngrep, er også utfyllende og gode. Pediatrisk anestesiologisk farmakologikapitlet bærer alt for mye preg av oppramsing og oppfattes ikke som nyttig. Med fordel kunne flere tabeller med doseringsanvisninger samt flere retningslinjer og råd vært satt inn her.

Til tross for en del mangler er dette en utmerket innføringsbok i barneanestesi for leger i spesialisering i anestesiologi og kan anbefales. Den kan også være nyttig for anestesisykepleiere samt sykepleiere og leger som er involvert i postoperativ behandling av barn på sykehus.

\section{Vegard Dahl}

Avdelingssjef, Anestesiavdelingen Akershus universitetssykehus 